\title{
Keberhasilan sambung samping tanaman durian (Durio zibenthinus $M$.) akibat konsentrasi IAA (Indole Acetic Acid) dan umur batang bawah yang berbeda
}

\author{
(The success of side grafting of durian plants due to the concentration of IAA (Indole \\ Acetic Acid) and different age of rootstock) \\ I. A. Fitriyanto, , Karno, dan B. A. Kristanto \\ Department of Agriculture, Faculty of Animal and Agricultural Sciences, Diponegoro University \\ Tembalang Campus, Semarang 50275 - Indonesia \\ Corresponding E-mail: irvanaf13@gmail.com
}

\begin{abstract}
The purpose of this research was to analyse the the success of side grafting of durian plants at various levels of IAA concentration and different age of rootstock. The research was arranged in factorial complete randomized design with the first factor was various concentrations of IAA $(0,75$ da $150 \mathrm{ppm})$ and the second factor was rootstock age $(6,9$, and 12 months). Each treatment was repeated 5 times. The parameters observed were the time of the success of the grafting, the time of bud breaking, length of shoots, number of open leaves, and width of the canopy. Data were analyzed for variance and continued by DMRT (Duncan Multiple Range Test). The results showed that there was no effect on the level of IAA concentration while the age level of the rootstock had a significant effect $(\mathrm{P}<0.05)$ on the number of open leaves and canopy widths. There was no interaction between the level of IAA and different age of rootstock against side grafting of durian varieties bawor.
\end{abstract}

Key words:, durian bawor, IAA, side grafting, age of rootstock

\begin{abstract}
ABSTRAK
Penelitian ini bertujuan untuk mengkaji keberhasilan sambung samping tanaman durian pada berbagai taraf konsentrasi IAA dan umur batang bawah yang berbeda. Penelitian disusun dengan rancangan acak lengkap faktorial dengan faktor pertama adalah konsentrasi auksin IAA $(0,75$ da 150 ppm) dan faktor kedua adalah umur batang bawah (6, 9, dan 12 bulan). Masing-masing perlakuan diulang 5 kali. Parameter yang diamati yaitu waktu keberhasilan sambungan, waktu pecah tunas, panjang tunas, jumlah daun terbuka, dan lebar tajuk. Data dianalisis ragam dan dilanjutkan uji DMRT (Duncan Multiple Range Test). Hasil penelitian menunjukkan bahwa tidak ada pengaruh pada taraf konsentrasi IAA sedangkan taraf umur batang bawah memberikan pengaruh nyata $(\mathrm{P}<0,05)$ terhadap jumlah daun terbuka dan lebar tajuk. Tidak ada interaksi antara taraf konsentrasi IAA dan umur batang bawah yang berbeda terhadap sambung samping durian vaietas bawor.
\end{abstract}

Kata kunci : durian bawor, IAA, sambung samping, umur batang bawah

\section{PENDAHULUAN}

Indonesia merupakan salah satu negara yang memiliki iklim tropis dan merupakan negara agraris, sehingga di negara ini sangat banyak ditemui berbagai macam lahan perkebunan. Sektor perkebunan di Indonesia terus berkembang terutama pada perkebunan hortikultura. Salah satu komoditas hortikultura yang banyak diminati oleh masyarakat Indonesia adalah durian (Tirtawinata et al., 2016). Buah durian banyak diminati karena memiliki rasa yang unik dan juga berbagai macam manfaat untuk kesehatan, sehingga memiliki nilai ekonomis yang cukup tinggi (Ashari, 2017). Minat yang begitu tinggi dari masyarakat Indonesia dalam mengkonsumsi 
durian menjadikan buah ini memiliki prospek unggulan yang baik untuk dikembangkan lagi, baik untuk ekspor maupun kebutuhan dalam negeri. Permintaan dan harga jual yang cukup tinggi, seharusnya diikuti juga dengan tingginya produktivitas buah durian. Akan tetapi yang terjadi di Indonesia, produksi buah durian dalam negeri belum mampu mencukupi kebutuhan domestik. Menurut (Badan Pusat Statistik, 2013) produksi buah durian Indonesia tahun 2012 sebanyak 888.130 ton. Permintaan pasar yang cukup tinggi memacu produsen menanam durian unggul dalam jumlah yang banyak, itu artinya bahwa ketersediaan bibit durian unggul juga harus banyak. Untuk mendapatkan bibit durian unggul bisa dilakukan dengan cara perbanyakan melalui generatif atau secara vegetatif (Pasaribu et al., 2016). Tanaman yang diperbanyak secara vegetatif umumnya dapat berbuah pada umur 3-5 tahun setelah tanam, sedangkan tanaman yang diperbanyak secara generatif akan berbuah pada umur 10-12 tahun setelah tanam.

Perbanyakan vegetatif dengan teknik sambung samping menjadi solusi yang tepat untuk menghasilkan bibit durian yang unggul. Sambung samping merupakan teknik menyambung batang bawah dan batang atas yang berasal dari jenis varietas lain yang diinginkan (Suwandi, 2003). Batang atas atau entres yang telah disambung akan terus tumbuh hingga menjadi tanaman baru dengan varietas yang disambungkan. Keberhasilan sambungan antara batang bawah dan batang atas dapat dipengaruhi oleh beberapa faktor diantaranya adalah keterampilan dalam menyambung, umur tanaman, diameter batang bawah dan lingkungan (Tambing et al., 2008). Kegagalan sambungan dapat disebabkan oleh umur batang bawah yang belum siap untuk disambung, oleh karena itu dalam menyambung tanaman durian umur batang bawah tanaman durian perlu diperhatikan untuk keberhasilan sambung samping tanaman durian. Keberhasilan perbanyakan tanaman durian secara vegetatif khususnya sambung samping dapat didukung dengan penambahan zat pengatur tumbuh (Sari dan Susilo, 2012). Berdasarkan penelitian sebelumnya penggunaan batang bawah dapat mempengaruhi hasil sambung pucuk pada tanaman manggis (Handayani et al., 2013). Penelitian lain menyatakan penggunaan umur batang bawah pada sambung bibit tanaman jeruk berpengaruh terhadap keberhasilan sambungan (Sutami et al., 2009)

Zat pengatur tumbuh yang dapat digunakan untuk merangsang pembentukan tunas adalah salah satunya auksin. Auksin merupakan salah satu zat pengatur tumbuh yang dapat digunakan untuk proses pembibitan durian, karena hormon tersebut dapat membantu dalam proses pembelahan sel dan mendorong terbentuknya kalus. Hormon auksin mampu memacu dan mendorong pembelahan sel pada kambium pembuluh (Lakitan, 2007). Hormon auksin akan memacu proses pembelahan sel, sehingga sambungan dapat tersambung dengan maksimal (Yulianto et al., 2015). Penambahan hormon auksin dan penggunaan batang bawah dengan umur yang tepat pada sambung samping tanaman durian akan meningkatkan keberhasilan sambung samping pada tanaman durian. Hal ini dikarenakan interaksi antara hormon auksin dengan umur batang bawah yang sesuai akan mempercepat proses penyambungan (Aeni et al., 2017). Berdasarkan penelitian sebelumnya menyatakan pemberian hormon auksin terhadap proses sambung samping tanaman srikaya berpengaruh nyata terhadap keberhasilan sambungan (Yulianto et al., 2015). Pemberian hormon IBA pada

Tabel 1. Waktu Keberhasilan Sambungan

\begin{tabular}{|c|c|c|c|c|}
\hline \multirow{2}{*}{$\begin{array}{c}\text { Umur Batang } \\
\text { Bawah }\end{array}$} & \multicolumn{3}{|c|}{ Konsentrasi IAA (ppm) } & \multirow{2}{*}{ Rata-rata } \\
\hline & 0 & 75 & 150 & \\
\hline & ----- & --- ha & --1י- & \\
\hline 6 bulan & 23,60 & 32,00 & 31,20 & 28,93 \\
\hline 9 bulan & 27,20 & 25,60 & 26,00 & 26,27 \\
\hline 12 bulan & 24,40 & 27,60 & 26,20 & 26,07 \\
\hline Rata-rata & 25,07 & 28,40 & 27,80 & \\
\hline
\end{tabular}


sambung pucuk tanaman alpukat memberikan pengaruh yang nyata, tanaman alpukat memberikan respon pada sambung pucuk (Pramudito et al., 2018). Penelitian lain pada tanaman jambu kristal pemberian hormon auksin IAA dengan dosis 100 ppm dan 200 ppm memberikan pengaruh nyata terhadap hasil sambung samping tanaman jambu kristal (Pratomo et al., 2017).

Penelitian ini bertujuan untuk mengkaji keberhasilan sambung samping tanaman durian pada berbagai taraf konsentrasi IAA dan umur

\section{Metode Penelitian}

Rancangan percobaan yang digunakan adalah rancangan acak lengkap (RAL) faktorial $3 \times 3$ dengan 5 Ulangan. Faktor pertama adalah konsentrasi IAA dengan 3 taraf perlakuan yaitu A0: 0 ppm, A1: 75 ppm, dan A2: 150 ppm. Faktor kedua adalah umur batang bawah dengan 3 taraf perlakuan yaitu B1: 6 bulan, B2: 9 bulan, dan B3: 12 bulan. Kombinasi antara dua faktor perlakuan menghasilkan 9 kombinasi perlakuan. Setiap kombinasi perlakuan dilakukan 5 kali ulangan

Tabel 2. Waktu Pecah Tunas

\begin{tabular}{|c|c|c|c|c|}
\hline \multirow{2}{*}{$\begin{array}{l}\text { Umur Batang } \\
\text { Bawah }\end{array}$} & \multicolumn{3}{|c|}{ Konsentrasi IAA (ppm) } & \multirow[b]{2}{*}{ Rata-rata } \\
\hline & 0 & 75 & 150 & \\
\hline & - n & - he & (12) & 3552 \\
\hline 9 bulan & 29,80 & $\begin{array}{l}36,40 \\
27,40\end{array}$ & $\begin{array}{l}43,20 \\
27,00\end{array}$ & $\begin{array}{l}35,53 \\
28,07\end{array}$ \\
\hline 12 bulan & 34,40 & 33,40 & 29,20 & 32,33 \\
\hline Rata-rata & 30,40 & 32,40 & 33,13 & \\
\hline
\end{tabular}

batang bawah yang berbeda, serta untuk mengetahui interaksi antara taraf konsentrasi IAA dan umur batang bawah terhadap pertumbuhan awal sambung samping tanaman durian.

\section{MATERI DAN METODE}

Penelitian ini dilaksanakan pada bulan September - Desember 2018 di lokasi Kebun Perbanyakan CV Mitra Bibit, Kabupaten Purworejo dan Laboraturium Fisiologi dan Pemuliaan Tanaman Fakultas Peternakan dan Pertanian Universitas Diponegoro Semarang

\section{Materi}

Bahan-bahan yang digunakan dalam penelitian ini adalah batang bawah durian dengan vairan umur 6, 9, dan 12 bulan, entres durian varietas bawor, IAA (Indhole Acetic Acid), aquades, alkohol $70 \%$. Alat yang digunakan antara lain erlenmeyer, gelas ukur, corong, timbangan analitik, spatula, cotton bud, selang, pisau okulasi, gunting dahan, plastik okulasi, plastik label, penggaris, kamera, dan alat tulis. sehingga diperoleh 45 unit percobaan. Data yang diperoleh dianalisis dengan menggunakan prosedur analisis ragam (analysis of variance / anova) pada taraf 5\%. Jika terdapat pengaruh perlakuan maka dilanjutkan uji wilayah ganda duncan untuk mengetahui perbedaan.

\section{Pelaksanaan}

Penelitian ini diawali dengan menyiapkan batang bawah umur 6, 9, dan 12 bulan. Pembuatan larutan IAA $75 \mathrm{ppm}$ ppm dan $150 \mathrm{ppm}$ membutuhkan $0,075 \mathrm{mg}$ dan $0,1 \mathrm{mg}$ bubuk IAA. Bubuk IAA ditimbang dan dimasukkan kedalam erlenmeyer $50 \mathrm{ml}$. Bubuk IAA ditetesi dengan 10 $\mathrm{ml}$ alkohol $70 \%$ dan digojog hingga larut. Aquades ditambahkan hingga volume mencapai $1000 \mathrm{ml}$. Pelaksanaan penyambungan diawali dengan menyiapkan entres dari tanaman durian varietas bawor. Selanjutnya, membuat jendela sambungan dan menyayat entres secara melintang dan sayatan diolesi hormon dengan cotton bud sesuai dengan perlakuan taraf konsentrasinya. Penyambungan dilakukan dengan menyisipkan entres pada jendela sambungan. Sambungan diikat 
dengan plastik okulasi dari bawah keatas secara rapat. Pemeliharaan tanaman meliputi penyiraman, penyiangan gulma dan pengendalian hama penyakit.

\section{Parameter Pengamatan}

Umur keberhasilan sambungan diamati setelah plastik sambungan dibuka, sambungan yang berhasil dapat dilihat dari entres yang masih segar dan entres mulai membesar. Waktu pecah tunas diamati setiap hari dengan ciri tunas mulai membelah. Panjang tunas diukur menggunakan penggaris dari pangkal tunas hingga pangkal daun teratas. Jumlah daun dihitung pada tiap minggu pengamatan. Daun yang dihitung adalah daun yang telah terbuka sempurna. Lebar tajuk diukur menggunakan penggaris dari ujung daun yang satu keujung daun yang lainnya yang menutupi bagian atas.

\section{HASIL DAN PEMBAHASAN}

\section{Waktu Keberhasilan Sambungan}

Hasil penelitian mengenai pengaruh taraf konsentrasi IAA dan umur batang bawah terhadap waktu keberhasilan sambungan disajikan pada diberikan, sehingga pemberian hormon auksin sebesar 75 ppm dan 150 ppm tidak memiliki pengaruh terhadap sambungan khususnya pada parameter waktu keberhasilan sambungan. Hal ini berbeda pada penelitian dari Kose dan Guleryuz (2006) yang menguji pengaruh auksin pada batang pohon anggur yang berbeda yang menunjukkan bahwa auksin merangsang terbentuknya kalus pada pertautan antara batang bawah dan entres. Pada penelitian ini tanaman durian tidak memberikan respon terhadap auksin yang digunakan untuk sambung samping, namun pada penelitian Kose dan Gulerys (2006) pada tanaman anggur pemberian auksin mampu merangsang pembentukan kalus pada pertautan sambungan.

Hasil analisis menunjukkan bahwa taraf umur batang bawah tidak memberikan pengaruh nyata terhadap waktu keberhasilan sambungan (Tabel 1). Ashari (2006) menyatakan umur batang bawah yang sesuai dapat mempengaruhi keberhasilan sambungan, karena apabila umur batang bawah yang digunakan terlalu muda ataupun terlalu tua akan berpengaruh pada proses pertautan sambungan. Pada penelitian ini penggunaan umur batang bawah tanaman durian tidak berpengaruh terhadap umur keberhasilan

Tabel 3. Panjang Tunas

\begin{tabular}{|c|c|c|c|c|}
\hline \multirow{2}{*}{$\begin{array}{c}\text { Umur Batang } \\
\text { Bawah }\end{array}$} & \multicolumn{3}{|c|}{ "Konsentrasi IAA (ppm) } & \multirow{2}{*}{ Rata-rata } \\
\hline & 0 & 75 & 150 & \\
\hline & & $----c$ & - & \\
\hline 6 bulan & 7,46 & 9,60 & 3,56 & 6,87 \\
\hline 9 bulan & 5,10 & 8,36 & 8,32 & 7,26 \\
\hline 12 bulan & 4,90 & 8,94 & 10,50 & 8,11 \\
\hline Rata-rata & 5,82 & 8,97 & 7,46 & \\
\hline
\end{tabular}

Tabel 1.

Hasil analisis menunjukkan bahwa taraf konsentrasi IAA tidak memberikan pengaruh nyata terhadap waktu keberhasilan sambungan (Tabel 1). Widyawati (2010) berpendapat bahwa hormon auksin berperan dalam memacu pembentukan kalus pada batang yang terluka dan mempercepat pembelahan sel. Hal ini tidak berpengaruh pada tanaman durian, tanaman durian tidak responsif terhadap hormon auksin yang sambungan. Namun Heryana et al. (2012) menyatakan bahwa diameter batang bawah pada tanaman karet mempengaruhi tingkat keberhasilan okulasi. Hal tersebut menandakan pada pada tanaman durian penggunaan umur batang bawah tidak berpengaruh pada parameter umur keberhasilan sambungan namun pada penelitian Heryana et al. (2012) umur batang bawah tanaman karet mempengaruhi keberhasilan okulasi. 
Tabel 4. Jumlah Daun Terbuka

\begin{tabular}{|c|c|c|c|c|}
\hline \multirow{2}{*}{$\begin{array}{l}\text { Umur Batang } \\
\text { Bawah (B) }\end{array}$} & \multicolumn{3}{|c|}{ Konsentrasi IAA (ppm) (A) } & \multirow{2}{*}{ Rata-rata } \\
\hline & 0 & 75 & 150 & \\
\hline & \multicolumn{4}{|c|}{ 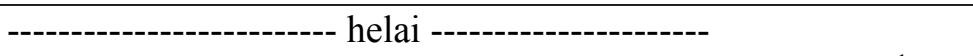 } \\
\hline 6 bulan & 2,00 & 1,80 & 0,40 & $1,40^{\mathrm{b}}$ \\
\hline 9 bulan & 1,40 & 3,80 & 4,00 & $3,06^{\mathrm{a}}$ \\
\hline 12 bulan & 1,20 & 2,00 & 2,00 & $1,70^{\mathrm{b}}$ \\
\hline Rata-rata & 1,50 & 2,50 & 2,10 & \\
\hline
\end{tabular}

Superskrip yang berbeda pada kolom rata-rata menunjukkan perbedaan nyata $(\mathrm{P}<0,05)$.

\section{Waktu Pecah Tunas}

Hasil analisis menunjukkan bahwa taraf konsentrasi IAA tidak memberikan pengaruh nyata terhadap waktu pecah tunas (Tabel 2).

Hasil analisis ragam menunjukkan bahwa taraf konsentrasi IAA tidak memberikan pengaruh nyata terhadap waktu pecah tunas (Tabel 2). Lakitan (2007) menyatakan bahwa auksin berperan dalam meningkatkan perkembangan sel pada tunas yang sedang berkembang, sehingga bisa mempercepat pembelahan sel pada calon bakal tunas. Pada penelitian ini perlakuan auksin untuk sambung samping tanaman durian tidak berpengaruh, hal ini dikarenakan tanaman durian tidak responsif terhadap pemberian hormon sintetis. Pada penelitian jambu kristal yang dilakukan oleh Pratomo et al. (2017) menyatakan bahwa pada tanaman jambu kristal pemberian hormon auksin sintetis dengan dosis $100 \mathrm{ppm}$ dan $200 \mathrm{ppm}$ memberikan pengaruh nyata terhadap hasil sambung samping tanaman jambu kristal. Hal ini menunjukan bahwa pada tanaman durian kurang responsif terhadap pemberian hormon auksin, namun pada tanaman jambu kristal responsif terhadap pemberian hormon auksin. Hal ini menunjukan bahwa pada tanaman durian kurang responsif terhadap pemberian hormon auksin, namun pada tanaman jambu kristal responsif terhadap pemberian hormon auksin.

Hasil analisis menunjukkan bahwa taraf umur batang bawah tidak memberikan pengaruh nyata terhadap waktu pecah tunas (Tabel 2). Suwandi (2003) menyatakan bahwa kondisi batang bawah dan entres harus sesuai, karena hal tersebut menunjang keberhasilan proses grafting. Pada penelitian ini penggunaan umur batang bawah tanaman durian yang berbeda menunjukan tidak ada berpengaruh khususnya pada parameter waktu pecah tunas. Penelitian yang dilakukan Sutami et al. (2009) menyatakan bahwa penggunaan umur batang bawah pada sambung bibit tanaman jeruk berpengaruh terhadap keberhasilan sambungan. Hal ini menunjukan bahwa setiap tanaman memiliki karakter yang berbeda-beda, pada tanaman durian umur batang bawah tidak mempengaruhi keberhasilan sambungan sedangkan pada penelitian Sutami et al. (2009) penggunaan umur batang bawah pada tanaman jeruk berpengaruh pada hasil sambungan.

\section{Panjang Tunas}

Hasil penelitian mengenai pengaruh taraf konsentrasi IAA dan Umur batang bawah disajikan pada Tabel 3.

Hasil analisis ragam menunjukkan konsentrasi IAA tidak berpengaruh nyata terhadap panjang tunas. Darmanti (2009) berpendapat bahwa auksin dapat meningkatkan proses pembelahan sel pada tanaman, sehingga dapat mempengaruhi pemanjangan tunas pada tanaman. Pada penelitian ini pemberian hormon auksin pada proses sambung samping tanaman durian tidak berpengaruh nyata terhadap panjang tunas. Hal ini berbeda dengan penelitian Yulianto et al. (2015) yang menyatakan bahwa pemberian auksin terhadap sambung samping tanaman srikaya berpengaruh nyata terhadap keberhasilan sambungan. Hal ini menunjukkan bahwa setiap tanaman memiliki respon yang berbeda-beda terhadap hormon auksin yang diberikan. Hal ini menunjukkan bahwa setiap tanaman memiliki respon yang berbeda-beda terhadap hormon auksin yang diberikan, pada tanaman durian auksin tidak berpengaruh terhadap sambungan 
Tabel 5. Lebar Tajuk

\begin{tabular}{|c|c|c|c|c|}
\hline \multirow{2}{*}{$\begin{array}{l}\text { Umur Batang } \\
\text { Bawah }\end{array}$} & \multicolumn{3}{|c|}{ Konsentrasi IAA (ppm) } & \multirow{2}{*}{ Rata-rata } \\
\hline & 0 & 75 & 150 & \\
\hline & \multicolumn{4}{|c|}{ 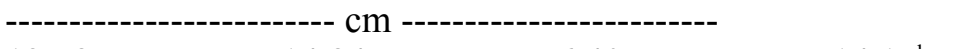 } \\
\hline 6 bulan & 12,78 & 14,84 & 6,40 & $14,15^{\mathrm{b}}$ \\
\hline 9 bulan & 15,12 & 17,04 & 18,70 & $14,71^{\mathrm{a}}$ \\
\hline 12 bulan & 7,74 & 14,74 & 14,90 & $13,02^{\mathrm{b}}$ \\
\hline Rata-rata & 11,88 & 15,54 & 13,33 & \\
\hline
\end{tabular}

Superskrip yang berbeda pada kolom rata-rata menunjukkan perbedaan nyata $(\mathrm{P}<0,05)$.

sedangkan pada tanaman srikaya berpengaruh terhadap keberhasilan.

Hasil analisis ragam menunjukkan umur batang bawah tidak berpengaruh nyata terhadap parameter panjang tunas. Ashari (2006) menyatakan batang bawah yang sehat dapat mempengaruhi keberhasilan sambung samping tanaman durian. Pemberian perlakuan batang bawah dengan umur yang berbeda pada sambung samping tanaman durian tidak memberikan pengaruh yang nyata terhadap parameter panjang tunas. Sari dan Susilo (2012) menyatakan bahwa penggunaan umur batang bawah yang berbeda memberikan pengaruh nyata terhadap keberhasilan sambungan pada tanaman kakao. Hal ini membuktikan bahwa pada tanaman durian penggunaan umur batang bawah tidak berpnegaruh nyata, namun pada tanaman kakao penggunaan umur batang bawah yang berbeda memberikan pengaruh nyata terhadap keberhasilan sambungan.

\section{Jumlah Daun Terbuka}

Hasil penelitian mengenai pengaruh taraf konsentrasi IAA dan Umur batang bawah disajikan pada Tabel 4.

Hasil analisis ragam pada Tabel 4 menunjukkan bahwa konsentrasi IAA yang berbeda tidak memberikan pengaruh yang nyata terhadap jumlah daun yang terbuka. Supriyanto dan Saepulloh (2014) menyatakan bahwa peran hormon auksin dapat meningkatkan proses pembelahan sel. Pada penelitian ini pemberian perlakuan hormon auksin dengan konsentrasi 75 ppm dan 150 ppm pada sambung samping tanaman durian tidak memberikan pengaruh nyata pada prameter jumlah daun terbuka. Pada penelitian Pramudito et al. (2018) menyatakan bahwa pemberian hormon auksin pada sambung pucuk tanaman alpukat memberikan pengaruh yang nyata, tanaman alpukat memberikan respon kepada hormon auksin yang diberikan pada sambung pucuk. Hal ini menandakan bahwa setiap tanaman memiliki respon yang berbeda-beda, pada tanaman durian pemberian auksin tidak memberikan pengaruh nyata terhadap umur keberhasilan sambungan, namun pada penelitian Pramudito et al. (2018) pemberian auksin pada sambung pucuk alpukat memberikan pengaruh nyata terhadap sambungan.

Hasil analisis menunjukkan bahwa umur batang bawah berpengaruh nyata $(\mathrm{P}<0,05)$ terhadap jumlah daun yang terbuka. Sutami et al. (2009) berpendapat bahwa pemilihan batang bawah berpengaruh terhadap keberhasilan sambungan dan jumlah daun yang dihasilkan. Pada penelitian ini batang bawah umur 9 bulan memiliki hasil yang paling optimum pada parameter jumlah daun terbuka dibandingkan dengan umur batang bawah 6 bulan dan 12 bulan. Hal ini sesuai dengan pendapat Sudjijo (2009) yang menyatakan proses pertautan sambungan yang baik akan mengantarkan hara yang diserap akar ke daun dan sebaliknya disalurkan ke seluruh bagian tanaman. Proses pembelahan sel memerlukan energi tinggi yang diserap oleh akar, proses metabolisme dalam tanaman dapat terganggu akibat jaringan tanaman yang buruk, maka biosintesis hormon bekerja tidak optimal, akibatnya pertumbuhan dan perkembangan daun akan terhambat. Sehingga dari penelitian ini umur dan kondisi batang bawah dapat mempengaruhi terhadap jumlah daun yang dihasilkan. 


\section{Lebar Tajuk}

Hasil penelitian mengenai pengaruh taraf konsentrasi IAA dan Umur batang bawah disajikan pada Tabel 5.

Hasil analisis ragam Tabel 5. menunjukkan konsentrasi IAA tidak berpengaruh nyata terhadap lebar tajuk. Campbell et al. (2003) menyatakan pemberian hormon IAA dapat mempecepat proses pembelahan sel dan meningkatkan laju pemanjangan pada sel tanaman. Pada penelitian ini pemberian auksin pada sambung samping tanaman durian tidak berpengaruh terhadap lebar tajuk yang dihasilkan. Pada penelitian yang dilakukan Rochmatino dan Prayoga (2011) menyatakan pemberian hormon auksin pada sambung pucuk tanaman adenum berpengaruh nyata terhadap keberhasilan sambungan. Hal ini menunjukan bahwa masing-masing tanaman memilii respon yang berbeda, tanaman durian tidak responsif terhadap hormon auksin yang diberikan, namun pada penelitian Rochmatino dan Prayoga (2011) tanaman adenum responsif terhadap hormon auksin.

Hasil analisis menunjukkan umur batang bawah berpengaruh nyata $(\mathrm{P}<0,05)$ terhadap parameter lebar tajuk. Pada penelitian ini batang bawah umur 9 bulan memiliki hasil yang paling optimum pada parameter lebar tajuk dibandingkan dengan umur batang bawah 6 bulan dan 12 bulan. Hal ini sesuai dengan pendapat Pakpahan et al. (2012) yang menyatakan lebar tajuk dapat dipengaruhi oleh kondisi batang yang sehat dan memiliki akar yang sehat, karena penyerapan nutrisi yang maksimal akan meningkatkan pertumbuhan dari tanaman seperti jumlah daun dan tunas. Handayani et al. (2013) yang menyatakan bahwa penggunaan batang bawah dapat mempengaruhi keberhasilan sambung pucuk pada tanaman manggis. Hal ini membuktikan bahwa batang bawah berpengaruh pada hasil sambung samping tanaman durian khususnya pada parameter lebar tajuk, umur batang bawah juga berpengaruh pada sambung pucuk tanaman manggis.

\section{KESIMPULAN}

Pemberian hormon auksin IAA tidak berpengaruh utnuk proses sambung samping tanaman durian, hal ini menunjukkan tanaman durian tidak responsif terhadap pemberian hormon IAA. Berdasarkan parameter jumlah daun terbuka dan lebar tajuk, batang bawah umur 9 bulan memiliki hasil terbaik dibandingkan dengan batang bawah umur 6 dan 12 bulan, selain parameter tersebut semua batang bawah umur 6 dan 12 bulan dapat digunakan untuk sambung samping guna memperoleh hasil yang optimum.

\section{DAFTAR PUSTAKA}

Aeni, N., S. Salman, M. D. Sukmasari. 2017. Cara perbanyakan vegetatif dan pemberian zat pengatur tumbuh terhadap pertumbuhan tunas pada tanaman jeruk nipis (Citrus aurantifolia swingle). Agrivet Journal. 5 (2) : 5-14.

Ashari, S. 2006. Hortikultura: Aspek Budidaya. Edisirevisi. UI-Press, Jakarta.

Ashari, S. 2017. Durian : King of Fruits. UB Press, Malang.

Badan Pusat Statistik Indonesia. 2013. Indonesia dalam angka. Jakarta: Badan Pusat Statistik Indonesia.

Campbell, N.A., J.B. Reece., L.G. Mitchel. 2003. Biologi. Edisi 5: Jilid 2. Erlangga. Jakarta.

Darmanti, S. 2009. Struktur dan perkembangan daun acalypha indica yang diperlakukan dengan kombinasi IAA dan GA pada konsentrasi yang berbeda. BIOMA. 11 (1) : 17-22.

Handayani, R. S., R. Poerwanto., Sobir., A. Purwito., dan T. M. Ermayanti. 2013. Pengaruh batang bawah dan jenis tunas pada mikrografting manggis secara in vitro. J. Agronomi Indonesia. 41 (1) : 4753.

Heryana, N., Saefudin., dan I. Sobari. 2012. Pengaruh umur batang bawah terhadap presentase keberhasilan okulasi hijau pada tiga klon karet. Jurnal TIDP. 1 (2). 95-100.

Kose, C. and M. Guleryuz. 2006. Effect of auxins 
and cytokinins on graft union of grapevine (Vitis vinivera) New Zealand. J. Crop Hortic. Sci. 34. 145-150.

Lakitan, B. 2007. Dasar-dasar Fisiologi Tumbuhan. Raja Grafindo Persada, Jakarta.

Pakpahan, T. P., P. D. Bandem, dan Patriani. 2012. Pengaruh panjang entris terhadap keberhasilan sambung pucuk bibit jambu air. J. Sains Mahasiswa Pertanian. 1 (1): 19.

Pramudito, K. Karno, dan E. Fuskah. 2018. Efektifitas penambahan hormon auksin (IBA) dan sitokinin (BAP) terhadap sambung pucuk alpukat. J. Agro Complex. 2 (3) : 248-253.

Pratomo, H., K. Karno, dan B. A. Kristanto. 2018. Pengaruh konsentrasi IAA (indole acetic acid) dan BAP (benzil amino purin) terhadap pertumbuhan awal sambung samping jambu biji (Psidium guajava L.) Var. Kristal. J. Agro Complex. 2 (1) : 2935.

Rochmatino, dan L. Prayoga. 2011. Pengaruh pemberian NAA dan sitokinin terhadap pertumbuhan hasil teknik sambung adenium. Agritech. 8 (2): 96-104.

Sari, I. A. Dan A. W. Susilo. 2012. Keberhasilan sambungan pada beberapa jenis batang bawah atas dan famili batang bawah kakao. Pelita Perkebunan. 28(2). 72-81.

Sudjijo. 2009. Pengaruh ukuran batang bawah dan batang atas terhadap pertumbuhan durian monthong, Hepe, dan DCK-01. J. Hortikultura. 19 (1) : 89-94.
Supriyanto dan A. Saepulloh. 2014. Pengaruh bahan stek dan hormon IBA (Indole Butiric Acid) terhadap pertumbuhan stek jabon merah (Anthocephalus macrophyllus). Jurnal Silvikultur Tropika (5) : 104-112.

Sutami, A Mursyid, dan G. M. S. Noor. 2009. Pengaruh umur batang bawah dan panjang entres terhadap keberhasilan sambung bibit tanaman jeruk siam banjar label biru. Agroscience. 16 (2):121-127.

Suwandi. 2003. Petunjuk teknis perbanyakan tanaman dengan cara sambungan (Grafting). Balai Besar Penelitian Bioteknologi dan Pemuliaan Tanaman Hutan. Yogyakarta.

Tambing, Y., E. Adelina, T. Budiarti, dan E. Murniati. 2008. Kompatibilitas batang bawah nangka tahan kering dengan entris nangka asal Sulawesi Tengah dengan cara sambung samping. Agroland. 15 (2) : 95100.

Tirtawinata, M. R., P. J. Santoso, dan L. H. Apriyanti. 2016. Durian: Pengetahuan Dasar untuk Pecinta Durian. Penebar Swadaya, Jakarta.

Widyawati, G. 2010. Pengaruh variasi konsentrasi naa dan bap terhadap induksi kalus jarak pagar (Jatropha curcas). Program Studi Biosains. Universitas Sebelas Maret, Surakarta.

Yuliyanto, A. G., E. Setiawan, E. dan K. Badami. 2015. Efek pemberian IBA terhadap pertautan sambung samping tanaman srikaya. Jurnal Agrovigor. 8 (2) : 51-56. 